\title{
Instagram as Media in Teaching Writing Recount Text for Senior High School Students
}

Abdul Basith

Ahmad Syafi' $i^{2}$

1 Corresponding Author, English Education Department, STKIP Al Hikmah, Surabaya, Indonesia; basithibnabbas@gmail.com

${ }^{2}$ English Education Department, STKIP Al Hikmah, Surabaya, Indonesia ;

ahmadsyafii20@gmail.com

\begin{abstract}
Social media is web-based application that allows users to communicate, collaborate, and share resources with other people. Both being easy to access and easy to use make social media become an effective way to communicate and exchange ideas. Students can use social media to keep up with their friends, to stay up-to-date with news and current events, to fill up spare time, to find entertaining content, and to share opinions. The use of social media becomes famous for the students nowadays. Thus, the popularity of the social media among students can be used as a tool in language teaching. One of the famous social media is Instagram. Instagram is a social network that enables its users to take pictures and videos, and share them publicly or privately on the application, as well as through a variety of other social network. Through Instagram the students can post their photos or videos that can be commented by viewers. By using Instagram, teachers are offered great opportunity to develop classroom activities creatively. This paper will give an overview of the use of Instagram in teaching writing recount text in senior high school students.
\end{abstract}

Keywords: Instagram; Recount Text; Writing.

\section{Introduction}

According to Ministry of National Education decree 69 about basic background and curriculum structure (2013), writing focuses in genre texts. Some of them are descriptive text, narrative text, report text, recount text, etc. According to this paper, the focus of the text is recount text. According to Anderson, recount text is a piece of text that retells past events, usually the order in which they happened. The purpose of recount text is to give the readers or listeners a description of what occurred and when it occurred. According to syllabus, students are expected (1) can analyze social function and text structure on recount text, (2) can capture the meaning of recount text, (3) can arrange or write a simple text of recount text based on their experience.

There are several problems related in learning process (Syafi'i, 2017), such as: (1) writing class was described inactive class, (2) students' attitude and motivation toward writing was low, (3) students were passive in asking questions about writing to teacher. The 
problems above are considering by several causes; (1) the students mostly did the writing activity in the classroom (2) there is no media variation in teaching recount text.

Media is an important thing in English language teaching process. Christine (2017) stated that media can be connector in delivering topic to students. In addition, media also can improve students' motivation in English language teaching process. According to the ministry of National Education (2009), there are several media that can be used by the teacher in teaching process picture, reliable or real object, chart, poster, and cartoon, black and white board, audio media, over-head projector, and LCD projector.

Visual media used in learning process to make students easy in improving students' English ability. There are several forms of visual media which is used by teacher. For example; video, slide, picture or illustration. Thresia (2015) stated that picture is easy to be found from many sources.

Instagram is becoming highly used by the students. It makes users an instant way to draw and share the life moments with people through kinds of picture and video (Fitri, 2016). Teachers can use this media in developing activities creatively. Manampiring (2015) stated Instagram is social media which focuses on photos and videos in short duration with the caption. Another opinion, Listiani (2016) stated that Instagram is a fun quick form to share humans' life with others through a series of pictures. Moreover, Instagram is one of media in teaching language that can be used in English language learning process.

As one of social media, Instagram is become familiar used by the students. Besides, Instagram has the benefits such as Instagram can motivate students in writing recount text because they share their own picture with their short story as the caption then uploaded it in the internet. In addition, Listiani (2016) argued that Instagram is unique media with many features in supporting students' purpose related to the students' daily needs and education such as photo sharing, social and education.

All of the support features on Instagram is appropriate to teach recount text because recount text tells about past experience by retelling events that have occurred. In solving the problems above, the writer offer Instagram as media in teaching writing recount text. Crowley (2015) argued several reasons to use social media in teaching writing (1) social media provides places for students to share their stories (2) social media helps students in recognizing the power of personal voice. Therefore, Instagram is an appropriate media in English language teaching process. Teachers can use this media in developing certain activity creatively.

Based on the explanation above, it is important to students with the media which involves students interested. One of the ways to deal with is by using Instagram as Media in Teaching Writing Recount Text at Senior High School.

\section{Instagram}

Instagram is a new form of communication by using the medium pictures and videos. Instagram is currently one of the most famous popular social network sites in the world by over 300 million users (Instagram Press, 2015). In addition, Kelly (2015) stated that the focus of Instagram is for users to post individual images or videos with a description on their profile. Some 70 million images and videos are posted daily. 


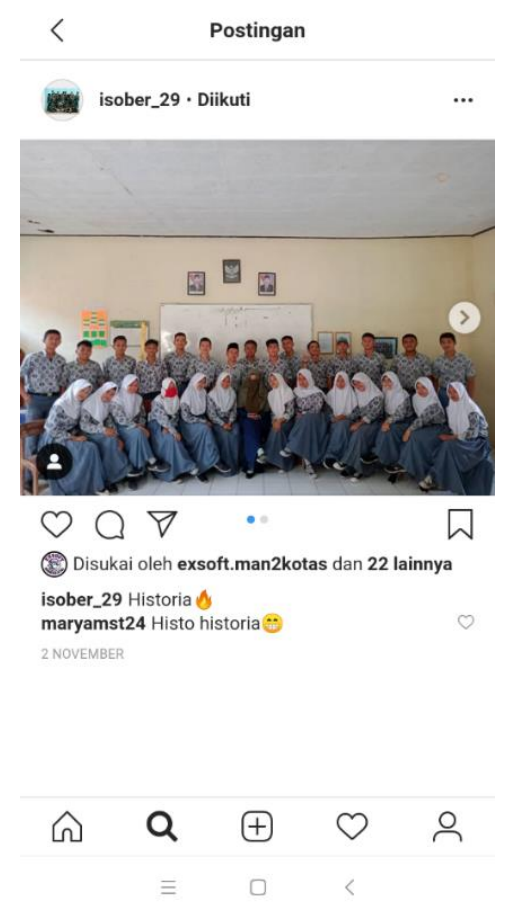

Figure 1. (Instagram Features)

Instagram has specific contents which are commonly used by users (Handayani, 2016). The contents can be described in the following:

1. Instagram profile interface

This part contains of user profiles information such as biography, profile photo, number of posts, and users' follower.

2. Profile content

This part contains viewers to scroll down the profile. Viewers can see all profile photos. For the closer look, viewers may click on any photo. The photo being chosen is displayed clearly.

3. Instagram's photo

In this part, viewers may like photos, give comments, or read previously posted comments. In this part also provides how many people have "liked" photo, photo's caption, and comments below the caption. Photos found on Instagram may also be used to motivate creatively, have students choose photos and then write a short story based on what they look.

4. Navigational tools

There are five icons available at the bottom of each page in Instagram's screen icons are home page, explore page, posting page, notification page, and user's profile page. When users post their photo or video, users can tag photo by adding location, tagging friends, and putting key words tags to photo. 


\section{Instagram in ELT}

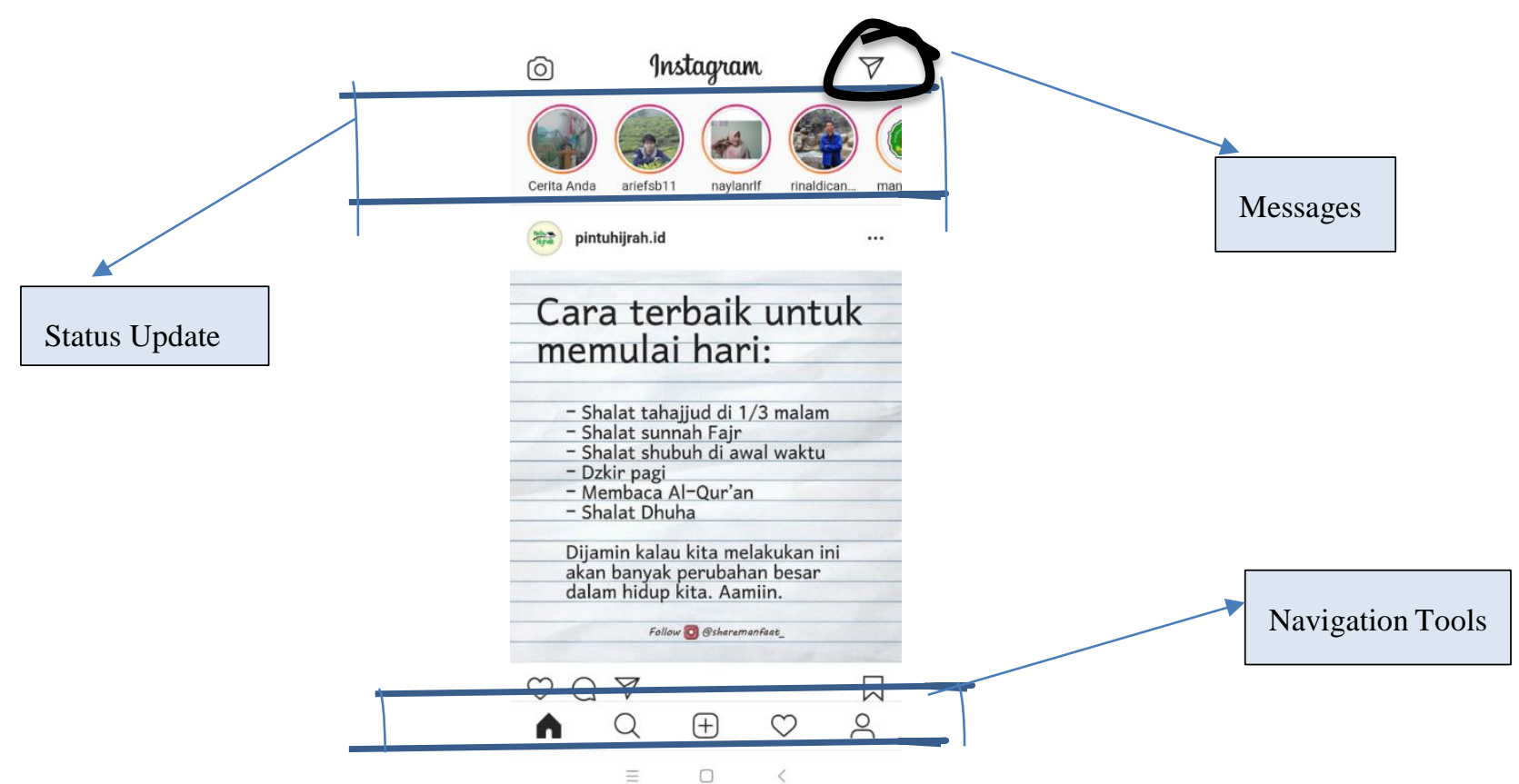

Figure 2.

The benefit of using Instagram are making the students interest in writing recount text because they share their picture with a caption or short story the upload it into internet.

In addition, Listiani (2016) stated that Instagram is interesting with various features in supporting students' aim related to daily needs and education such as:

1. Photo Sharing

Instagram allows the user to take pictures within the application or use photos that already exist in user's camera roll. Users can give their photo a title, which is helpful and fun. The title itself can make people curious about what is actually going on.

2. Social

Instagram, like any other social network, is based on having friends or followers. On Instagram, users 'follow' people. At the top of the profile (or anyone's profile) the user will see the username, profile pic, how many photos have been uploaded, how many followers the account has, and how many they are following. When users follow someone, their photos show up in their stream. The other things people can do here are like photos and comment on them. Both are appreciated. People ask questions in the comments, like "where was this taken" or "what app did you use for that?" It's currently a very friendly community. 


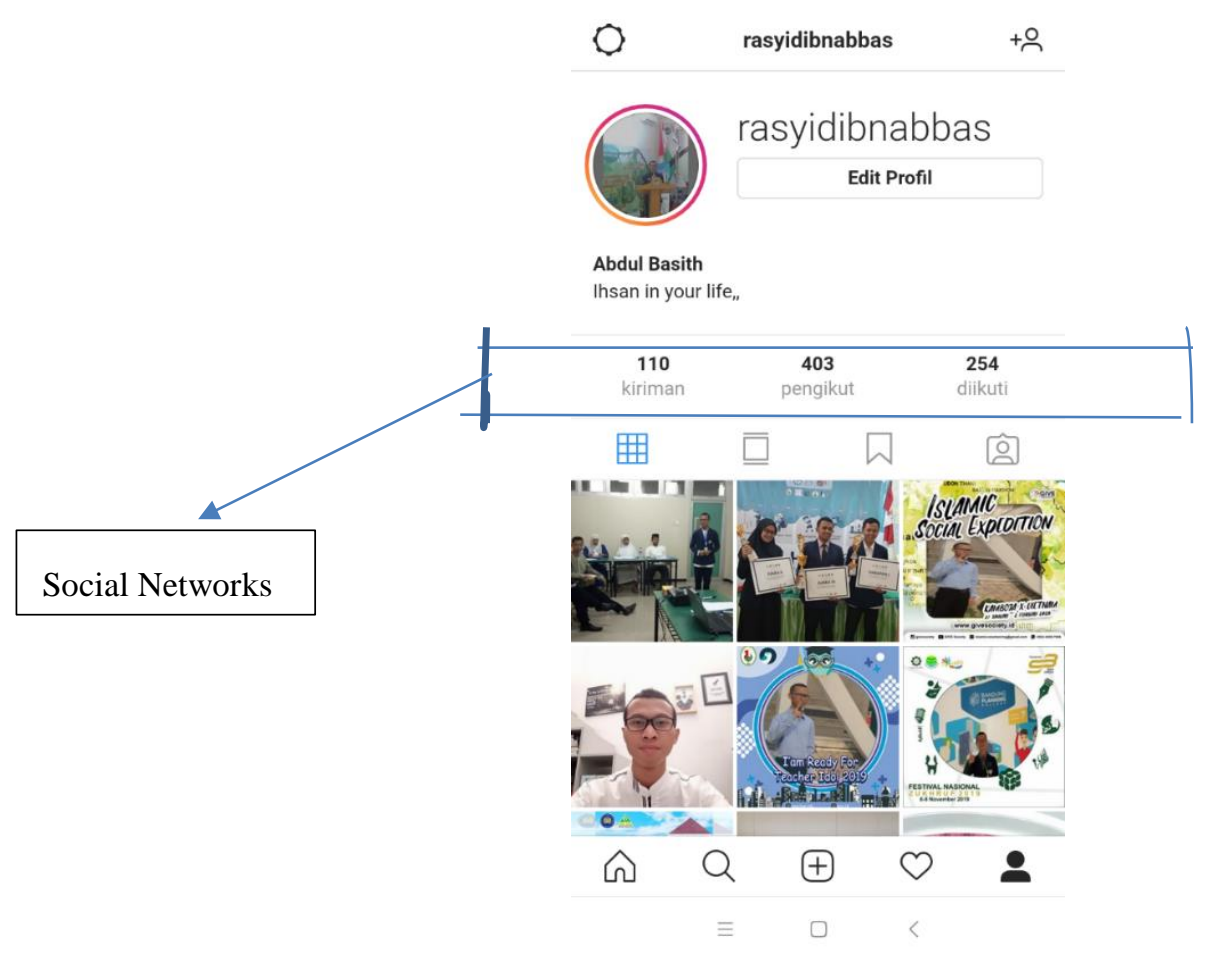

Figure 3.

3. The Community

People's experience on Instagram has been extremely enjoyable. Instagram connects people around the world. It's a very global community and has many advantages for students to express their feeling by writing something. It means when students are involved in a community they will try to make better move, in this case is their products in writing recount text.

4. An Education on our Shared Humanity

Those features of Instagram are great opportunity to teach students writing skill. Students involve in a good atmosphere of writing recount text because when working on their project they will get better insight from the picture uploaded. Pictures make them think wider and will support them in arranging a text in provided space because what they write is based on their personal life's experience.

In other opinion, Novitasari and Alivi (2016) stated that there are several beneficial uses of Instagram that can provide students in writing process: 1) make writing easier to share, 2) support group works, feedbacks, and collaborations, 3) provide opportunities in writing outside of class, 4) Instagram can link related texts and multimedia, and 5)provide students with a sense of authorship.

\section{Teaching Recount Text Using Instagram}

Learning does not always come from books or other text-based documents. In addition, Fitri (2016) stated that students can learn by themselves in various ways including through visual images. Instagram provides students accesses to thousands of photos every day and also allows them to add their own videos. By taking and responding photos or videos, students can learn to communicate in a different way and have a chance to build their critical thinking and creative skills.

According to Novitasari and Alivi (2016) mentioned the roles of implementing Instagram as the media in teaching writing recount text; 
1. Topic selection

The teachers ask students to choose topic to be written and posted it in Instagram. In this term, students should make an example of a short of recount text. The kind of the text can be personal recount, historical recount, biography, etc. The students should post the picture with the caption.

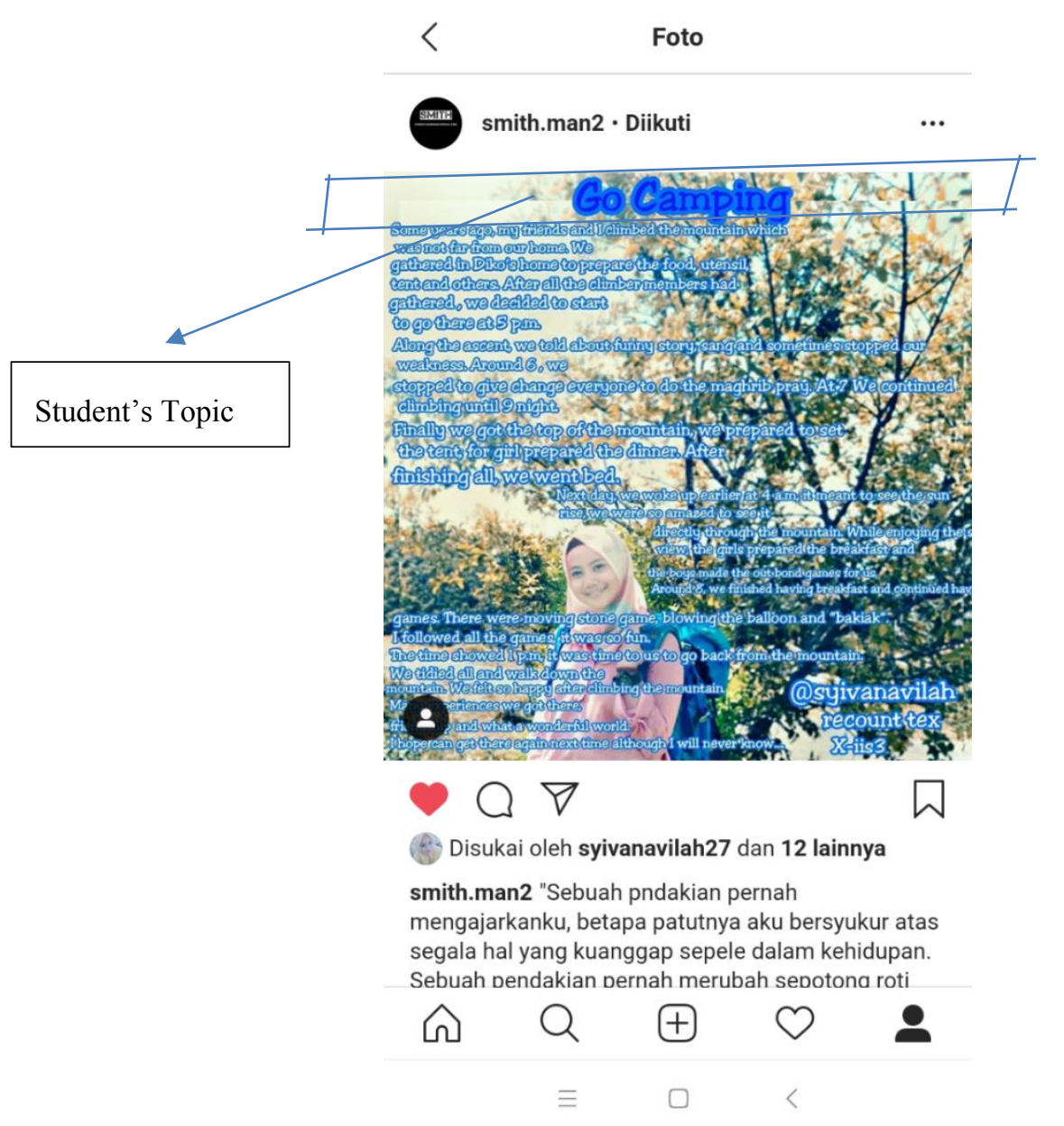

Figure 4.

2. Pre-writing activities

For aims of developing an interesting topic related to the students' text, an example of recount text is created. Eventually, the teacher can encourage students to search on their own for the additional information on the internet. However, it is important for teach students in choosing the information clearly on the internet.

3. Drafting

In this part, students were ready to begin drafting for their text. In helping students write the text, the teachers provide guidelines on how to write the text. Next, students fill the guidelines that give by teacher.

4. Peer review or teacher feedback

In this part, the students exchanged papers for peer revision. Peer correction is important to get feedbacks or inputs from audiences and make students learn to accept constructive criticism. Peer feedback helps students in improving their writing. 


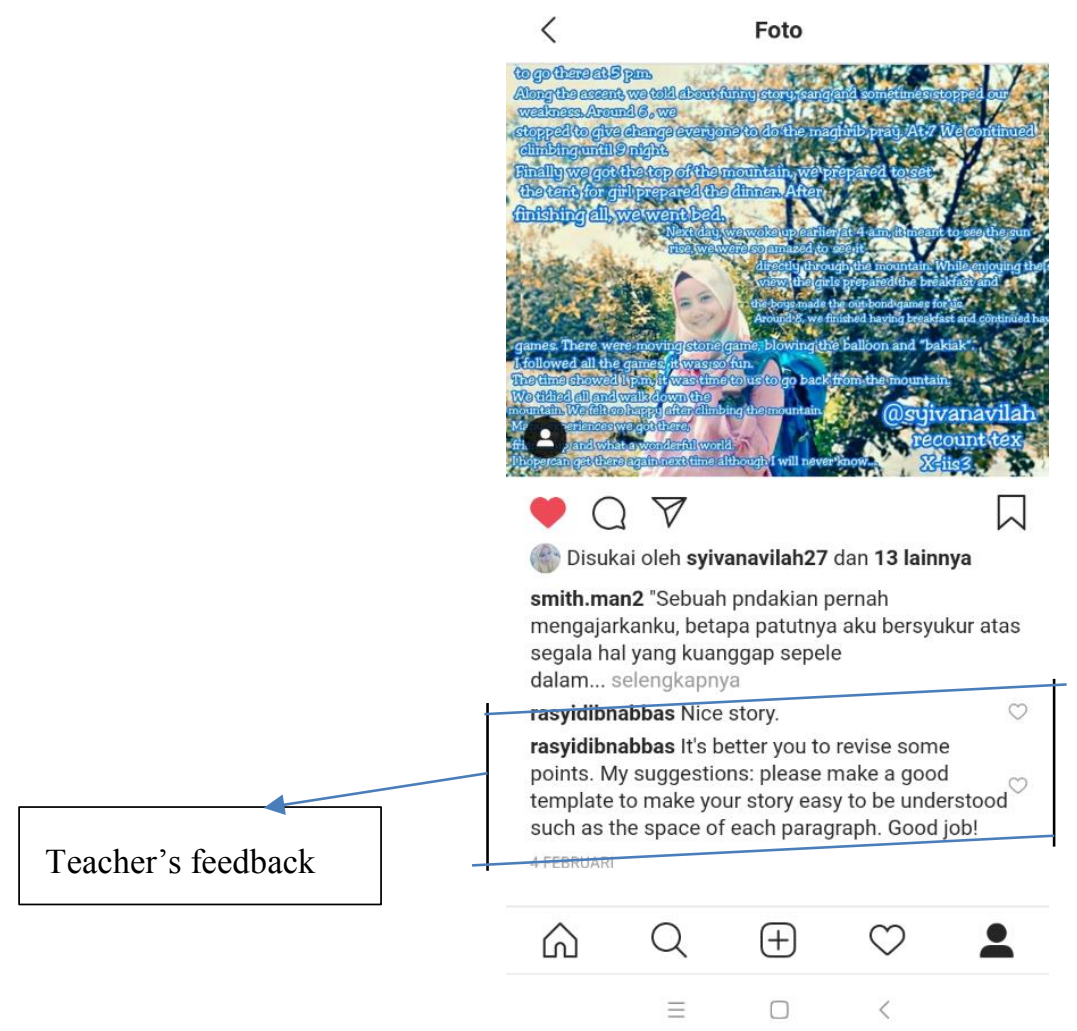

Figure 5.

5. Revising

In this part, teacher should guide the students to revise their writing with some guidelines such as organizations. Next, students revise the text based on teacher's feedback before they upload it into Instagram.

6. Sharing the written production on Instagram

In this part, students are ready to upload their writing on the Instagram. The teacher may give feedback or comment in column below the caption in term of making the students write better for the next time. The students also can write some hashtags for connecting the other users. Therefore, their posts can be seen and connected by many viewers. 


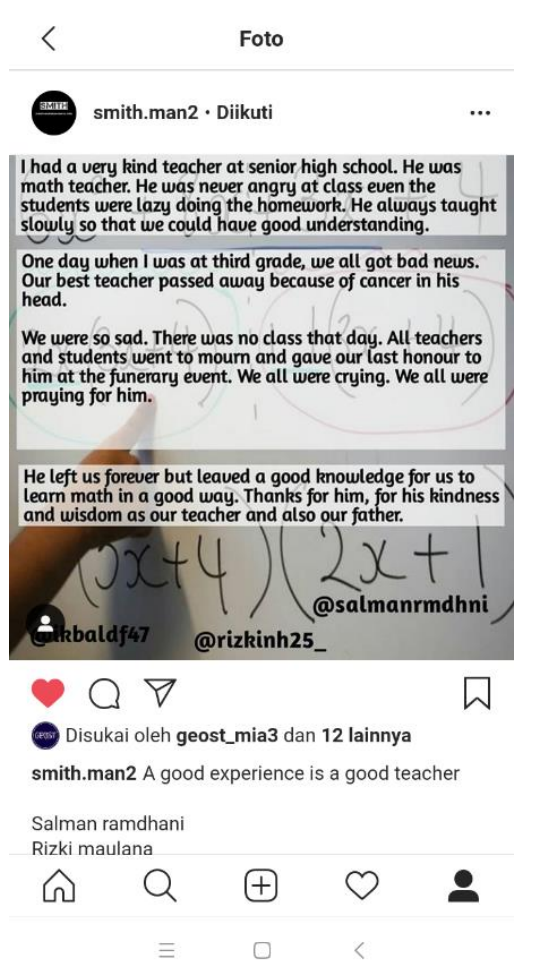

Figure 6. (Student's work)

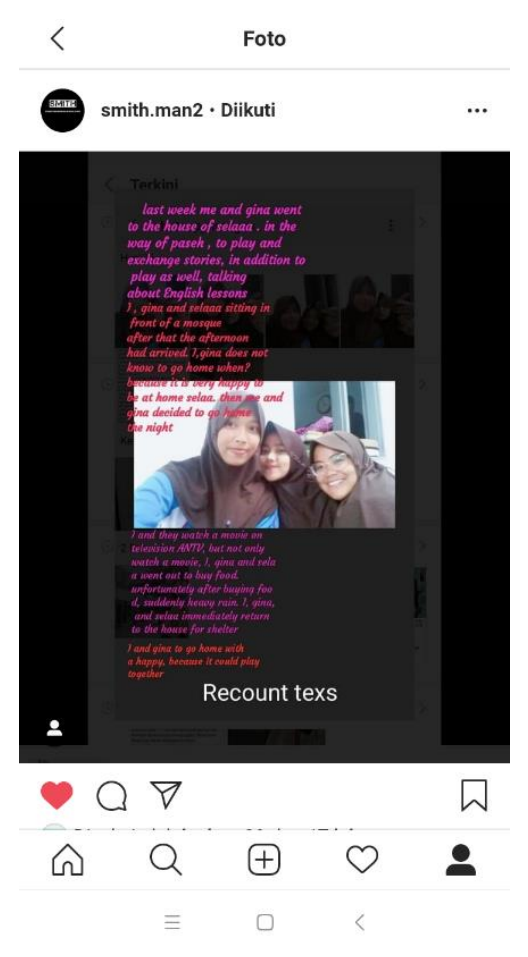

Figure 7. (Student's work)

\section{Conclusion}

Having discussed about Instagram and the activities provided by using Instagram, it can be summarized that Instagram as the media gives beneficial effect in helping teacher in teaching writing recount text. Instagram is useful of education tool in giving students and teachers an easy and enjoy way to communicate inside or outside the classroom. Using Instagram allows students to show students' ideas with contextually-relevant content and offers them a learning experience that they enjoy. Therefore, Instagram as the media can help teacher in teaching writing recount text. Other, students also fell enjoy in learning by using Instagram. Finally, it can be emphasized that using Instagram in learning can be an innovative media as it is used by students and teacher for educational aims appropriately.

\section{References}

Christine, L. K. (2017). The importance of education media in teaching. Buletin of social education, 20. 165- 169.

Crowley, Brianna. (2015). Connecting a Classroom: Reflections on Using Social Media With My Students [Online]. Available: http://www.edweek.org/tm/articles/2015/09/09/connecting-aclassroom-reflectionson-using-social.html. [3 November 2019].

Fenny, et al. (2018). Enhancing accounting students' writing skill through Instagram. 6th International Conference on English Language and Teaching (ICOELT 2018). Advances in Social Science, Education and Humanities Research, volume 276. 
Handayani, Fitri. (2016). Instagram as a Teaching Tool? Really? Proceedings of the Fourth International Seminar on English Language and Teaching (ISELT-4).

Kelly, R. (2015). An Exploration of Instagram to Develop ESL Learners' Writing Proficiency. Unpublished Master's Dissertation. British Council: Ulster University.

Listiani. (2016). The effectiveness of Instagram writing compared to teacher centered writing to teach recount text to students with high and low motivation. Journal of English Teaching, 5(1).

Manampiring. (2015). Peranan media sosial dalam interaksi sosial antar siswa SMAN 1 Manado. e-journal 'Acta Diurna', 4(2).

Novitasari and Alivi. (2016). Instagram: Social Media as an Instructional Tool to Teach Writing in Large Classes. The 8thNational English Language Teachers and Lecturers Conference (NELTAL) (pp.168-172). Malang: Department of English, Faculty of Letters: State University of Malang Press.

Syafi'I, Ahmad. (2017). The Implementation of Process Genre Based Approach (PGBA) Using Cartoon Movie (CARMOV) to Improve Students' Skill in Writing Narrative Text. International Seminar on Language, Education, and Culture. Proceedings: Faculty of Letters, Universitas Negeri Malang. 
